\author{
L.I. Ovsiannikova, G.V. Lashkarev, V.V. Kartuzov, D.V. Myroniuk, \\ M.V. Dranchuk, A.I. Ievtushenko
}

\title{
The Study of the Behavior of Al Impurity in ZnO Lattice by a Fullerene Like Model
}

\author{
Frantsevich Institute for Problems of Materials Science, NASU, Kyiv, Ukraine, earsen@ukr.net
}

\begin{abstract}
The fullerene like $\mathrm{Zn}_{32} \mathrm{Al}_{4} \mathrm{O}_{36}$ clusters were investigated and the oxygen interstitial $\mathrm{O}_{\mathrm{i}}$ acceptor intrinsic defect formation energy as well as Al ionization energy were calculated. The effect of lattice packing defects on the electroactivity of $\mathrm{Al}$ impurity in $\mathrm{ZnO}$ was investigated. Analysis of the defects formation energies shows the smaller formation energy of interstitial $\mathrm{O}_{\mathrm{i}}$ in a comparison with a formation of $\mathrm{Zn}$ vacancy. This allows us to formulate recommendations of technological conditions for films deposition, with improved electroactivity of $\mathrm{Al}$ donor.

Keywords: fullerene like model; zinc oxide; $\mathrm{Al}$ ionization energy; native defects formation energies; $\mathrm{ZnO}$ packing defects.
\end{abstract}

Received 5 March 2021; Accepted 5 April 2021.

\section{Introduction}

For the development of deposition technology and for control the properties of $\mathrm{ZnO}$ films doped by $\mathrm{Al}$ or other donor impurities as well as for their applications in photovoltaic and optoelectronic devices, the minimization of donor impurities compensation by native acceptor defects $\left(\mathrm{V}_{\mathrm{Zn}}, \mathrm{O}_{\mathrm{i}}\right.$ etc. $)$ is strongly required. An exponential dependence of defects concentration on their formation energy results in the situation when almost only defects with minimal energy are presented in any semiconducting material. For determination the thermodynamic properties of defects we started series of computational experiments.

The effectivity of semiconductor doping by donor impurity (for example $\mathrm{Al}$ in $\mathrm{ZnO}$ ) is determined by its electroactivity (EA). The electroactivity means the number of conductivity electrons which donor impurity atom delivers to conduction band (1 electron in the case of $\mathrm{Al}$ doped $\mathrm{ZnO}$ means $\mathrm{EA}=1$ ). The real $\mathrm{Al}$ electroactivity in $\mathrm{ZnO}$ lower than 1 , because of different reasons. The main of them is aluminum compensation by acceptor native defects: zinc vacancies $\left(\mathrm{V}_{\mathrm{Zn}}\right)$ or oxygen interstitials $\left(\mathrm{O}_{\mathrm{i}}\right)[1]$.

The purpose of this article is the determination of the influence of the intrinsic $\mathrm{O}_{\mathrm{i}}$ defects and packing defects of $\mathrm{ZnO}$ on the $\mathrm{Al}$ electroactivity in the $\mathrm{ZnO}$ lattice using a fullerene-like model i.e. FL $\mathrm{Zn}_{36} \mathrm{O}_{36}$ cluster. The choice of such cluster as a model for $a b$ initio quantum chemical study is due to the fact that isolated $(\mathrm{ZnO})_{n}$ clusters exist really and have been synthesized experimentally [2].

The information about formation of isolated clusters $(\mathrm{ZnO})_{\mathrm{n}}$, where $\mathrm{n}=1-100$, was published in $[2,3]$. The authors reported that zinc oxide clusters have been processed by laser ablation of zinc peroxide in vacuum and investigated by time-of-flight (TOF) mass spectroscopy. Experimental results revealed unpredicted and hitherto unknown $(\mathrm{ZnO})_{\mathrm{n}}$ clusters of enhanced stability ("magic clusters"). Cage-like structures for the magic clusters have been suggested and supported by firstprinciples calculations.

We fulfilled our own $a b$ initio study of a number of $(\mathrm{ZnO})_{\mathrm{n}}$ clusters [4] and came to the decision that the most suitable for investigating behavior of the impurity in $\mathrm{ZnO}$ lattice are clusters $\mathrm{Zn}_{36} \mathrm{O}_{36}$ and $\mathrm{Zn}_{48} \mathrm{O}_{48}$ because of their stability and high symmetry, which leads to saving of computation resources.

We successfully used fullerene like (FL) cluster model earlier for a solution of band engineering problems in $\mathrm{Zn}_{1-\mathrm{x}} \mathrm{Cd}_{\mathrm{x}} \mathrm{O}$ alloys and precipitation of $\mathrm{CdO}$ phase in 
these alloys (spinodal decomposition) [4-7]. The investigations showed that a substitution of $\mathrm{Zn}$ atoms by Cd ones [7] leads to the reduction of cluster stability and monotonous decrease of energy gap with growing $\mathrm{Cd}$ content. The $\mathrm{CdO}$ phase inclusion to $\mathrm{FL} \mathrm{Zn}_{44} \mathrm{Cd}_{4} \mathrm{O}_{48}$ cluster leads to non-monotonic rapid increase of cohesive energy i.e. cluster stability followed by band-gap energy shrinkage. The energy advantage belongs to a cluster with a nonhomogeneous distribution of Cd impurity.

\section{Model and computation technique}

As the basis of the model, an isolated $\mathrm{FL} \mathrm{Zn}_{32} \mathrm{Al}_{4} \mathrm{O}_{36}$ cluster was chosen to study its cohesive and electronic properties with different distribution of Al-O pairs [2, 8], the defect formation energies of $\mathrm{V}_{\mathrm{Zn}}$ [8], effect of intrinsic $\mathrm{O}_{\mathrm{i}}$ defects [1], and packing defects on the electroactivity of the $\mathrm{Al}$ impurity in the $\mathrm{ZnO}$ lattice. Qualitative results for the behavior of $\mathrm{Al}$ impurity in FL cluster based on $\mathrm{ZnO}$ were obtained [8]. Al impurity tends to homogeneous distribution in such cluster. Analysis of the defects formation energies shows the smaller formation energy of interstitial $\mathrm{O}_{\mathrm{i}}$ in a comparison with a formation of $\mathrm{Zn}$ vacancy. The $\mathrm{FL} \mathrm{Zn}_{36} \mathrm{O}_{36}$ cluster was investigated also to study packing defects in the $\mathrm{ZnO}$ lattice.

Geometrically, the $\mathrm{Zn}_{36} \mathrm{O}_{36}$ cluster is a polyhedron with 72 vertexes, which is restricted by 6 square and 32 hexagonal facets, at the vertexes of which $\mathrm{Zn}$ and $\mathrm{O}$ atoms are located. Each $\mathrm{Zn}$ atom is surrounded by $3 \mathrm{O}$ atoms and vice versa. As a macromolecule, the $\mathrm{Zn}_{36} \mathrm{O}_{36}$ cluster is a single-layer hexagonal $\mathrm{ZnO}$ plane folded into the sphere, which consists of 6-membered $\mathrm{Zn}-\mathrm{O}$ rings. The folding of the $\mathrm{ZnO}$ plane into the sphere occurs as a result of the replacement of a series of 6-membered rings by 4membered rings. Four-membered rings provide the convolution of the $\mathrm{ZnO}$ plane into a sphere, similar to the case when 5-membered rings ensure the convolution of the graphene plane into fullerene. As a result, the $\mathrm{Zn}_{36} \mathrm{O}_{36}$ FL cluster consists of six 4-membered rings and thirty two 6-membered $\mathrm{Zn}-\mathrm{O}$ rings. Four-membered rings are centers of structural stresses in the $\mathrm{Zn}_{36} \mathrm{O}_{36}$ cluster, because of distortions of the electron population on atoms, valence angles and the length of the interatomic bond $\mathrm{Zn}-\mathrm{O}$ in them (Tab. 1, Fig. 1).

In this paper, we consider the 4-membered ring in

Table 1

Characteristics of $\mathrm{Zn}_{36} \mathrm{O}_{36}$ cluster: Bond $\mathrm{Zn}-\mathrm{O}$ is the length of interatomic $\mathrm{Zn}-\mathrm{O}$ bond, Angles are valence angles, Mull.pop. is the number of electrons on atoms by Mulliken* in electron amount (calculated in approximation B3LYP/6-31d).

\begin{tabular}{|c|c|c|c|c|c|}
\hline Ring type & $\begin{array}{c}\text { Bond Zn-O length } \\
(\AA)\end{array}$ & $\begin{array}{c}\text { Angles O-Zn-O } \\
(\mathrm{deg})\end{array}$ & $\begin{array}{c}\text { Angles Zn-O-Zn } \\
(\mathrm{deg})\end{array}$ & $\begin{array}{c}\text { Mull.pop. } \\
\text { on Zn (e) }\end{array}$ & $\begin{array}{c}\text { Mull.pop. } \\
\text { on O (e) }\end{array}$ \\
\hline 6-membered & 1.88 & 115.55 & 119.7 & $29.08 ;$ & 8.99 \\
\hline 4-membered & 1.94 & 89.4 & 89.97 & 29.05 & 8.94 \\
\hline $\begin{array}{c}\text { 6-membered } \\
\text { adjacent to the } \\
\text { 4-membered }\end{array}$ & $1.88-1.89$ & 124.77 & 114.02 & 29.03 & 8.99 \\
\hline
\end{tabular}

* The analysis of the electron populations of the orbitals according to Mulliken is a procedure for determining the electron charges of atoms in a molecule and the electron populations of the overlapping orbitals. It is performed by equal distribution of the overlap between two atomic orbitals of chemically bound atoms. The electron density associated with the diffuse orbital is attributed to the atom on which this orbital is centered. Electron population on $\mathrm{Zn}$ and $\mathrm{O}$ ions testifies to ionic-covalent bond in $\mathrm{ZnO}$.
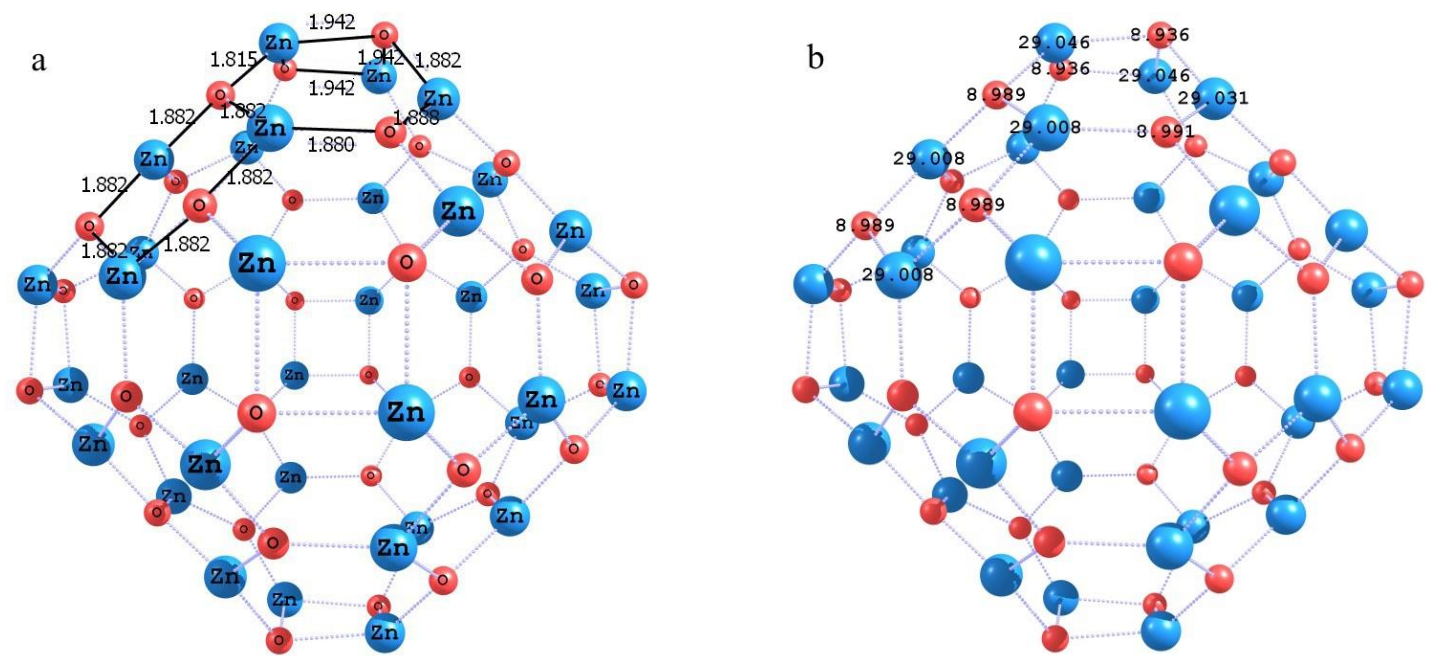

Fig. 1. The $\mathrm{Zn}_{36} \mathrm{O}_{36}$ cluster characteristics: a) lengthes of interatomic bonds $(\AA)$, black color denotes the bonds in the 6- and 4-membered rings; b) electron populations on atoms. 
cluster as a model of a local structural feature in the $\mathrm{ZnO}$ lattice similar to a partial dislocation (packing defect). The substitution of the $\mathrm{Zn}$ atom by the $\mathrm{Al}$ atom in the 4-membered ring we consider as a model for the replacement of $\mathrm{Zn}$ atoms by the $\mathrm{Al}$ impurity in the region of the packing defect in the $\mathrm{ZnO}$ lattice.

In this article the isolated $\mathrm{FL} \mathrm{Zn}_{32} \mathrm{Al}_{4} \mathrm{O}_{36}$ cluster was chosen to study the effect of intrinsic defects $\left(\mathrm{O}_{\mathrm{i}}\right)$, and packing defects on the electroactivity of the $\mathrm{Al}$ impurity in the $\mathrm{ZnO}$ lattice. In this cluster four zero charged threevalent $\mathrm{Al}$ impurity atoms substitute four two-valent $\mathrm{Zn}$ atoms in cation sublattice of $\mathrm{Zn}_{36} \mathrm{O}_{36}$ cluster (Fig. 2).

The calculations of optimized geometry, full energy and electronic structure were fulfilled in the frames of electronic density functional theory with B3LYP hybrid functional (in which the exchange energy was calculated using the Hartree-Fock method) with the MINI [9] basis set. Inasmuch as the used computational resources were restricted only the relative data were calculated in this paper which magnitudes can be compared (largersmaller). The cohesive energy of cluster was computed as a difference between the total energy of the cluster and the total energy of noninteracting constituent atoms without taking into account the energy of zero vibrations. The cohesive energy of $\mathrm{FL} \mathrm{Zn}_{32} \mathrm{Al}_{4} \mathrm{O}_{36}$ cluster is equal $208.8 \mathrm{eV}$.

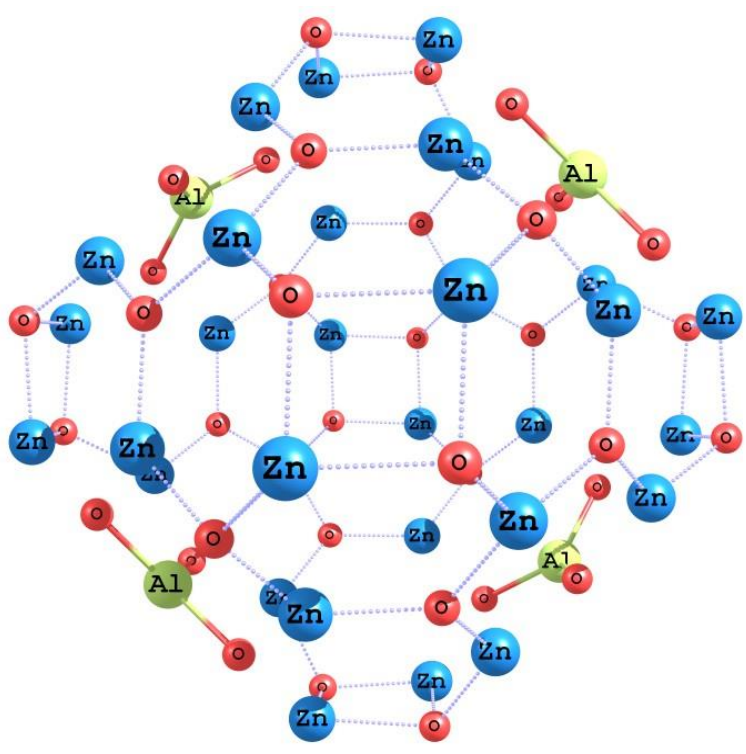

Fig. 2. Geometry of the FL $\mathrm{Zn}_{32} \mathrm{Al}_{4} \mathrm{O}_{36}$ cluster with homogenious distribution of Al-O pairs; yellow ball - $\mathrm{Al}$, blue ball $-\mathrm{Zn}$, red ball $-\mathrm{O}$.

At substituting $\mathrm{Zn}$ atoms by four $\mathrm{Al}$ atoms in $\mathrm{Zn}_{36} \mathrm{O}_{36}$ FL cluster with a formation of $\mathrm{Zn}_{32} \mathrm{Al}_{4} \mathrm{O}_{36}$ the hybridized molecular levels associated with $\mathrm{Al}$ arise. The energy gap between the highest occupied level associated with Al ( $\mathrm{E}_{\text {НОмо }}$ ) and the lowest unoccupied level of the conduction band $\left(\mathrm{E}_{\mathrm{LUMO}}\right)$ was evaluated as $0.71 \mathrm{eV}$. In this paper this energy gap we consider further within the terminology of semiconductor physics band structure as relative ionization energy of $\mathrm{Al}$ donor $\mathrm{E}_{\mathrm{i}}=0.71 \mathrm{eV}$.

At the application of calculation results obtained in the frames of cluster model to solid state it is necessary to take into account that energy gap $\mathrm{E}_{\mathrm{g}}$ of solid state is impossible to estimate at calculations of clusters containing several dozens of atoms. Only at the number of atoms aspiring to the infinity the magnitude of calculated energy gap will approach to experimental data [10]. The calculation method and the set of basic functions limit the accuracy for absolute magnitudes of energy parameters also. But for the comparison estimations for basic $\mathrm{Zn}_{32} \mathrm{Al}_{4} \mathrm{O}_{36}$ FL cluster and studying clusters with different space distribution of $\mathrm{Al}$ which were fulfilled at similar conditions the satisfactory qualitative relative results may be obtained.

On the basis of the developed model the calculations of the following energy characteristics for the mentioned $\mathrm{Zn}_{32} \mathrm{Al}_{4} \mathrm{O}_{36}$ FL clusters were performed: the most energy preferable Al impurity distribution; energies of zinc vacancy and oxygen interstitial formation, relative magnitudes of $\mathrm{Al}$ ionization energies.

GAMESS'09 [11], ChemCraft and Molekel 5.4 [12] programs were used for computations.

Table 2

Energy parameters of $\mathrm{Zn}_{32} \mathrm{Al}_{4} \mathrm{O}_{36}$ clusters with different space distribution of $\mathrm{Al}$ : $\mathrm{E}_{c}$ - the cohesive energy of cluster; $\mathrm{E}_{\mathrm{i}}$ - ionization energy of $\mathrm{Al}$.

\begin{tabular}{|c|c|c|c|}
\hline Variants & Position of $\mathrm{Al}$ & $\begin{array}{c}\mathrm{E}_{c} \\
(\mathrm{eV})\end{array}$ & $\begin{array}{c}\mathrm{E}_{\mathrm{i}} \\
(\mathrm{eV})\end{array}$ \\
\hline 1 & $\begin{array}{c}\mathrm{Al} \text { impurity atoms are } \\
\text { located in the 4-membered } \\
\text { ring }\end{array}$ & 203.73 & 0.86 \\
\hline 2 & $\begin{array}{c}\mathrm{Al} \text { impurity atoms are } \\
\text { located in the 6-membered } \\
\text { ring }\end{array}$ & 204.99 & 1.11 \\
\hline
\end{tabular}

\section{Results and discussion}

2.1. The influence of the Al spatial distribution in the $\mathrm{Zn}_{32} \mathrm{Al}_{4} \mathrm{O}_{36}$ cluster on its cohesive energy and the ionization energy of Al

The influence of packing defects in the $\mathrm{ZnO}$ crystal lattice on the electroactivity of the $\mathrm{Al}$ impurity was studied. The cohesion energy of clusters and the electroactivity of the $\mathrm{Al}$ impurity were calculated in the following cases: 1 ) the substitution of a $\mathrm{Zn}$ atom belonging to the 4-membered ring by an $\mathrm{Al}$ impurity; 2) the substitution of $\mathrm{Zn}$ atom belonging to the 6-membered ring by an $\mathrm{Al}$ impurity (Tab. 2). The arrangement of the $\mathrm{Al}$ atom in the 4-membered ring leads to a little bit smaller cohesion cluster energy and to significant decrease of the ionization energy of $\mathrm{Al}$ in comparison with the location in the 6-membered ring. Figure 3 shows electron density distribution on cluster atoms of the upper filled molecular orbital (HOMO).

It is seen from the Fig. 3 that the electron density is concentrated mainly on Al impurity atoms located in the 4-membered rings and in the neighboring 6-membered one.

As a result, an increase of the number of packing defects in the $\mathrm{ZnO}$ lattice leads to a decrease in cluster stability and an increase of the Al electroactivity. 


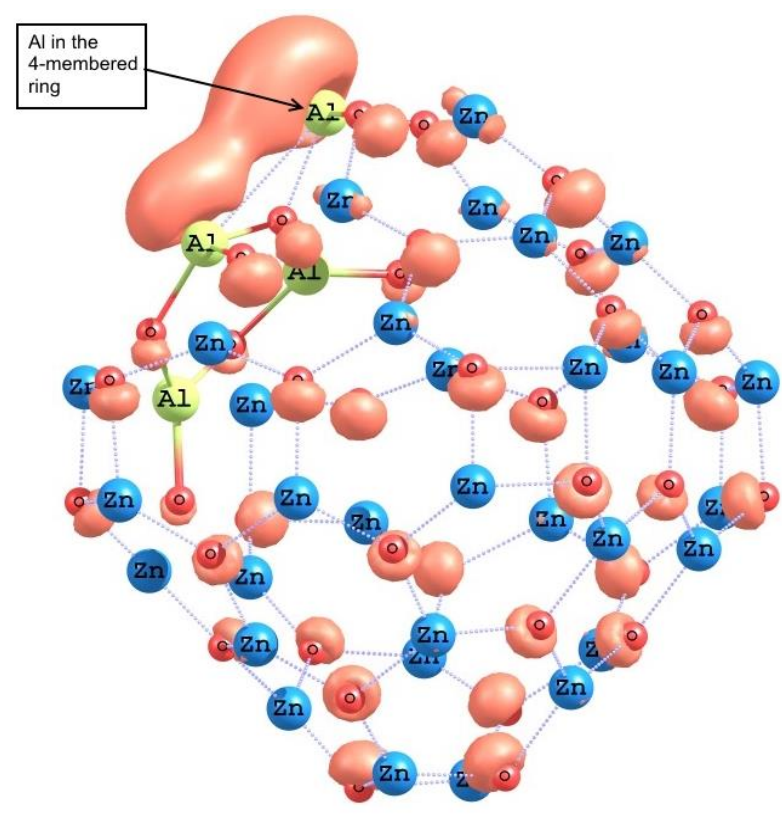

Fig. 3. The electron density distribution on cluster atoms for the higher occupied molecular orbital (HOMO); orange spheres - distribution of electron density.

2.2. The effect of the spatial allocation of oxygen interstitial relatively to $\mathrm{Al}$ on the formation energy of $\mathrm{O}_{i}$ and energy of $\mathrm{Al}$ ionization in the $\mathrm{Zn}_{32} \mathrm{Al}_{4} \mathrm{O}_{36}$ cluster

In $\mathrm{Zn}_{32} \mathrm{Al}_{4} \mathrm{O}_{36}$ cluster oxygen interstitial can be situated in two types of locations - near the $\mathrm{Al}$ atom and remotely to it. The calculations showed (Tab. 3, variant $a$, $b$ ) that the $\mathrm{O}_{\mathrm{i}}$ defect formation energy near $\mathrm{Al}$ is essentially smaller than at their remote location, respectively 0.44 and $3.13 \mathrm{eV}$. For these cases Al ionization energy is about 0.47 and $0.97 \mathrm{eV}$. Thus, at the $\mathrm{O}_{\mathrm{i}}$ location in the vicinity of $\mathrm{Al}$ the formation energy of this defect becomes more than 7 times lower and $\mathrm{Al}$ ionization energy diminishes about 2 times comparatively to the case of their remote disposition. Thus, the compensation of $\mathrm{Al}$ donor increases in this case.

The calculations of the defect $\mathrm{O}_{\mathrm{i}}$ formation energy and the $\mathrm{Al}$ ionization energy were carried out to determine the effect of the defect $\mathrm{O}_{\mathrm{i}}$ location near the packing defect of the $\mathrm{ZnO}$ lattice on the electroactivity of the Al impurity (Fig. 4, Tab. 3, variant $c-\mathrm{O}_{\mathrm{i}}$ adjacent to $\mathrm{Al}$ and 4membered ring). For this case, Fig. 4 shows the electron density distribution for the HOMO molecular orbital. The electron density is concentrated mainly on the atoms of embedded oxygen, and $\mathrm{O}$ atoms situated in the neighborhood. It can be seen from the Tab. 3, variant $c$ that the location of $\mathrm{O}_{\mathrm{i}}$ near 4-membered ring (the packing defect of the $\mathrm{ZnO}$ lattice) leads to a significant decrease in the formation energy of the defect $\mathrm{O}_{\mathrm{i}}(0.1 \mathrm{eV})$, compared with variants $a$ and $b$. Thus, from the analysis of the formation energy of the $\mathrm{O}_{\mathrm{i}}$ defect, the most probable is the variant $c$, then $a$, and then $b$. Defect $\mathrm{O}_{\mathrm{i}}$ formulated near the packaging defect becomes the leading one. In this case $(c)$, the ionization energy increases in comparison with the case $a$ and decreases insignificantly in comparison with the case $b$.

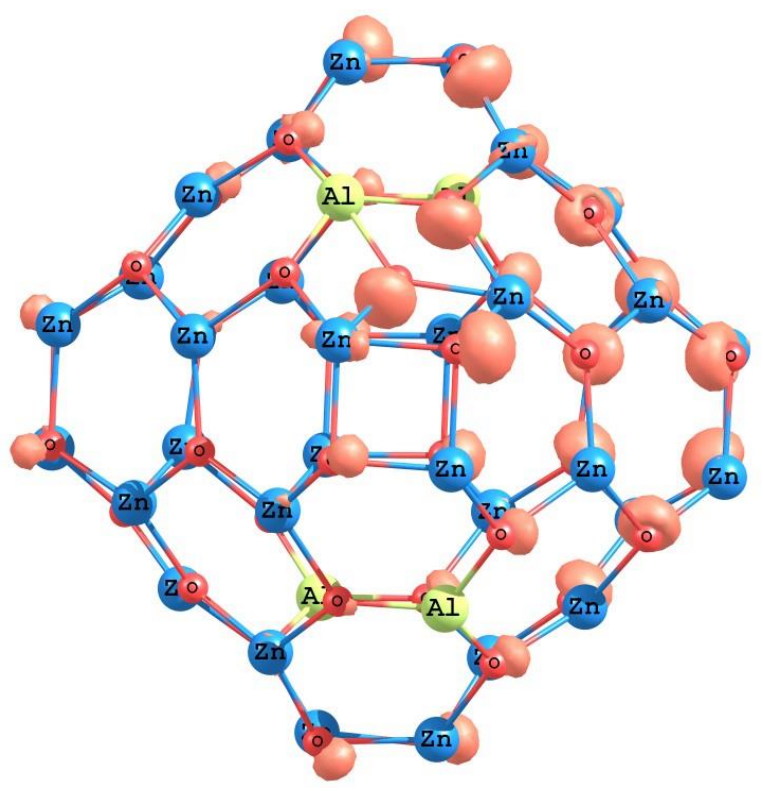

Fig. 4. The distribution of electron density on cluster atoms for the higher occupied molecular orbital (HOMO); the displacement of an oxygen atom (for variant $\mathrm{c}$ in the Tab. 3) where $\mathrm{O}_{\mathrm{i}}$ adjacent to $\mathrm{Al}$ and 4-membered ring; orange spheres are the distributions of electron density on cluster atoms for the higher occupied molecular orbital (HOMO).

Table 3

Energy parameters of $\mathrm{Zn}_{32} \mathrm{Al}_{4} \mathrm{O}_{36}$ clusters with different space distribution of $\mathrm{Al}$ : $\mathrm{E}_{\mathrm{Oi}}$ - defect formation energy; $\mathrm{E}_{\mathrm{i}}$ - ionization energy of Al. Variants:.a) $\mathrm{O}_{i}$ adjacent to the aluminum atom; b) $\mathrm{O}_{\mathrm{i}}$ is not adjacent to aluminum; c) $\mathrm{O}_{\mathrm{i}}$ adjacent to $\mathrm{Al}$ and 4-membered ring

\begin{tabular}{|c|c|c|}
\hline Variants & $\mathrm{E}_{\mathrm{Oi}}(\mathrm{eV})$ & $\mathrm{E}_{\mathrm{i}}(\mathrm{eV})$ \\
\hline $\mathrm{a}$ & 0.44 & 0.47 \\
\hline $\mathrm{b}$ & 3.13 & 0.97 \\
\hline $\mathrm{c}$ & 0.1 & 0.75 \\
\hline
\end{tabular}

\section{Conclusions}

Fullerene Like Model demonstrated its capability of living, what allows to use it in the future for the control of the electroactivity of donor impurities of the third group due to their compensation by intrinsic acceptor defects of $\mathrm{ZnO}$ crystal lattice and to look for technological ways for improving electroactivity of donor impurities in $\mathrm{ZnO}$. The results of theoretical calculations of $\mathrm{Al}$ ionization energy with adjacent $\mathrm{V}_{\mathrm{Zn}}$ and $\mathrm{O}_{\mathrm{i}}$ allowed us to formulate recommendations to the conditions of technological processes for deposition $\mathrm{ZnO}$ films with improved conductivity

The presence of packing defects in the $\mathrm{ZnO}$ lattice at the $\mathrm{O}_{\mathrm{i}}$ presence leads to an increase of $\mathrm{Al}$ ionization energy.

The $\mathrm{O}_{\mathrm{i}}$ location near the packing defect of the $\mathrm{ZnO}$ lattice and the $\mathrm{Al}$ impurity leads to a significant decrease of the formation energy for the $\mathrm{O}_{\mathrm{i}}$ defect, the defect becomes the leading one.

The presence of packing defects in the $\mathrm{ZnO}$ lattice leads to the predominant location of the $\mathrm{Al}$ impurity in the 
L.I. Ovsiannikova, G.V. Lashkarev, V.V. Kartuzov, D.V. Myroniuk, M.V. Dranchuk, A.I. Ievtushenko

defect region and to the increase of the Al electroactivity.

At summarizing the results, it should be mentioned that $\mathrm{E}_{\mathrm{i}}$ increasing at $\mathrm{V}_{\mathrm{Zn}}$ acceptor defects formation increases the compensation rate of $\mathrm{Al}$ impurity. This means that $\mathrm{Al}$ will pass it excess electron not to the gas of free carriers but to the nearest $\mathrm{V}_{\mathrm{Zn}}$ acceptor center. Inasmuch as $\mathrm{V}_{\mathrm{Zn}}$ is equivalent to oxygen excess, the $\mathrm{ZnO}$ films growth is necessary to carry out in the gas media with a lack of the oxygen. This will cause troubles to the $\mathrm{V}_{\mathrm{Zn}}$ acceptor defects formation. Another way is annealing $\mathrm{ZnO}$ films in vacuum.

$\mathrm{Al}$ diminishes the formation energy of $\mathrm{O}_{\mathrm{i}}$ acceptor defect, what increases a compensation of the $\mathrm{Al}$ donor impurity. Thus, in this case the lack of oxygen at $\mathrm{ZnO}$ film deposition is required also for $\mathrm{Al}$ electroactivity improving. The confirmation of this conclusion is the publication [13] where increasing of electrical conductivity for $\mathrm{ZnO}: \mathrm{Al}$ films was observed at diminishing partial oxygen pressure in working chamber at magnetron technology of film deposition.

Ovsiannikova L.I. - Candidate of Physical and Mathematical Sciences, Senior Researcher;

Lashkarev G.V. - Doctor of Physical and Mathematical Sciences, Professor, Head of Department;

Kartuzov V.V. - Candidate of Physical and Mathematical Sciences, Senior Researcher, Head of Department, Scientific Secretary;

Myroniuk D.V. - Candidate of Physical and Mathematical Sciences, Senior Researcher

Dranchuk M.V. - junior researcher;

Ievtushenko A.I. - Candidate of Physical and Mathematical Sciences, Senior Researcher, Head of Department.

[1] A. Ievtushenko, O. Khyzhun, I. Shtepliuk, and et. al., Journal of Alloys and Compounds 722, 683 (2017) (https://doi.org/10.1016/j.jallcom.2017.06.169).

[2] A. Dmytruk, I. Dmitruk, A. Kasuya, Materials Science \& Engineering Technology, 40(4), 265 (2009) (https://doi.org/10.1002/mawe.200800438).

[3] A. Dmytruk, I. Dmitruk, I. Blonskyy, and et. al., Microelectronics Journal 40, 218 (2009) (https://doi.org/10.1016/j.mejo.2008.07.010).

[4] L.I. Ovsiannikova, Acta Physica Polonica A 122, 1062 (2012) (https://doi.org/10.12693/APhysPolA.122.1062).

[5] L.I. Ovsiannikova, Acta Physica Polonica A 1261090 (2014) (https://doi.org/10.12693/APhysPolA.126.1090).

[6] L. Ovsiannikova, V. Kartuzov, I. Shtepliuk and et. al., Acta Physica Polonica A 129, 41 (2016) (https://doi.org/10.12693/APhysPolA.129.A-41).

[7] I. Shtepliuk, V. Khranovskyy, G. Lashkarev and et. al., Solid-State Electronics 81, 72 (2013) (https://doi.org/10.1016/j.sse.2013.01.015).

[8] L. Ovsiannikova, M. Dranchuk, G. Lashkarev and et. al., Superlattice and Microstructures 107, 1 (2017). (https://doi.org/10.1016/j.spmi.2017.03.054).

[9] S. Huzinaga, J. Andzelm, M. Klobukowski and et. al., Gaussian basis sets for molecular calculations Elsevier (Amsterdam, 1984).

[10] R.P. Messmer, G.D. Watkins, Phys. Rev. B 7, 2568 (1973) (https://doi.org/10.1103/PhysRevB.7.2568).

[11] M.W. Schmidt, K.K. Baldridge, J.A. Boatz and et. al., J. Comput. Chem. 14, 1347 (1993) (https://doi.org/10.1002/jcc.540141112).

[12] S. Portmann, H.-P. Lüthi, CHIMIA International Journal for Chemistry 54, 766 (2000).

[13] A.I. Ievtushenko, O.I. Bykov, L.O. Klochkov and et. al., Physics and Chemistry of Solid State 16(4), 667 (2015) (https://doi.org/10.15330/pcss.16.4.667-674).

\author{
Л.І. Овсяннікова, Г.В. Лашкарьов, В.В. Картузов, Д.В. Миронюк, \\ М.В. Дранчук, А.І. Свтушенко
}

\title{
Дослідження поведінки домішки Al у гратці ZnO за допомогою фулереноподібної моделі
}

\author{
Інститут проблем матеріалознавства ім. І.М. Францевича, НАН Украӥни, Київ, Украӥна, еarsen@ukr.net
}

\footnotetext{
Шляхом дослідження фулереноподібних кластерів $\mathrm{Zn}_{32} \mathrm{Al}_{4} \mathrm{O}_{36}$ було розраховано енергію утворення власних дефектів акцептора кисню $\mathrm{O}_{\mathrm{i}}$ та енергію іонізації $\mathrm{Al}$ в оксиді цинку. Досліджено вплив дефектів гратки на електроактивність домішки Al. Встановлено, що аналіз енергій утворення дефектів показує

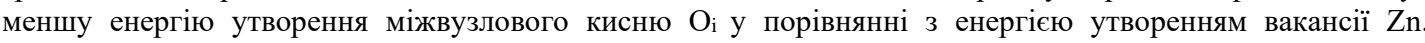
Проведені розрахунки дозволяють сформулювати рекомендації щодо технологічних умов осадження плівок $\mathrm{ZnO}$ із покращеною електроактивністю донорної домішки $\mathrm{Al}$.

Ключові слова: фулереноподібна модель; оксид цинку; енергія іонізації алюмінію; енергії утворення власних дефектів; дефекти упаковки $\mathrm{ZnO}$.
} 